\title{
İşgörenlere Yönelik Olarak Düzenlenen Rekreasyon Aktivitelerinin Örgütsel Sessizliğe Etkisi \\ (The Effect of Recreational Activities Organized for Employees on Organizational Silence)
}

\section{Pelin CANBOLAT iD a Ercan YAVUZ iD}

a Gazi Üniversitesi, Sosyal Bilimler Enstitüsü, Ankara, Türkiye. pelin filiz@hotmail.com

b Ankara Hacı Bayram Veli Üniversitesi, Turizm Fakültesi, Ankara, Türkiye. ercan.yavuz@hvb.edu.tr

\begin{tabular}{|c|c|}
\hline MAKALE BİLGİSİ & ÖZET \\
\hline Anahtar Kelimeler: & Amaç - Bu araştırmada; çalışanlar için düzenlenen rekreasyon aktivitelerinin önemini vurgulamak \\
\hline $\begin{array}{l}\text { Rekreasyon } \\
\text { Örgütsel Sessizlik }\end{array}$ & $\begin{array}{l}\text { ve rekreasyon aktiviteleri ile çalışanların sessizlik durumuna ait ilişkiyi ortaya koymak } \\
\text { amaçlanmıştır. }\end{array}$ \\
\hline Boşzaman & $\begin{array}{l}\text { Yöntem - Amaç doğrultusunda; demografik özellikler, rekreasyon ifadeleri ve örgütsel sessizlik } \\
\text { ölçeğinden yararlanılarak anket uygulaması yapılmıştır. İşgörenlerin sessizliği ile rekreasyon }\end{array}$ \\
\hline Gönderme Tarihi & aktiviteleri arasındaki ilişkilere ait sonuçlar saptanmış ve tablolara yansıtılmıştır. \\
\hline $\begin{array}{l}\text { Revizyon Tarihi } 20 \text { Haziran } 2019 \\
\text { Kabul Tarihi } 24 \text { Haziran } 2019\end{array}$ & $\begin{array}{l}\text { Bulgular - Araştırmaya } 388 \text { adet hizmet sektöründe çalışan birey katılmıştır. Sonuç olarak } \\
\text { araştırmaya katılan çalışanların örgütsel sessizliği ve rekreasyonel aktiviteler arasındaki ilişki } \\
\text { demografik özellikleri de göz önünde bulundurularak araştırmaya yansitılmıştır. }\end{array}$ \\
\hline Makale Kategorisi: & Tartışma - Calışanların rekreasyon aktivitelerine katılımlarına bă̆lı olarak sessizlik davranışları \\
\hline Araştırma Makalesi & $\begin{array}{l}\text { değişmektedir. Çalışanların mücadeleci, kararlı ve yeniliğe açık olmaları için rekreasyon aktiviteleri } \\
\text { ile motivasyonları yükseltilerek sessizliğe yönelik bir davranış göstermemelerini sağlamaktadır. } \\
\text { Çalışanların rekreasyon aktivitelerine katılımlarının düşük olması ise çalışanların çeşitli nedenlerle } \\
\text { sessiz kalmayı tercih etmelerine neden olmaktadır. }\end{array}$ \\
\hline
\end{tabular}

\begin{tabular}{ll}
\hline ARTICLE INFO & ABSTRACT \\
\hline $\begin{array}{l}\text { Keywords: } \\
\text { Recreation } \\
\text { Organizational Silence } \\
\text { Leisure }\end{array}$ & $\begin{array}{l}\text { Purpose - In this study; It is aimed to emphasizetheim portance of recreation activities organized for } \\
\text { employees and toreveal there lationship between the recreation activities and the silence status of } \\
\text { the employees. } \\
\text { Design/methodology/approach }- \text { For the purpose; Demographic characteristics, recreation } \\
\text { expressions and organizational silence scale were used in the questionnaire. The results of the } \\
\text { relationship between employee silence and recreation activities were determined and reflected in } \\
\text { the tables. }\end{array}$ \\
$\begin{array}{l}\text { Received 5 April 2019 } \\
\text { Revised 20 June 2019 }\end{array}$ & $\begin{array}{l}\text { Findings }-388 \text { employees participated in the study. As a result, there lation ship between the } \\
\text { organizational silence and recreational activities of the participants was reflected to the study } \\
\text { Accepted 24 June 2019 }\end{array}$ \\
$\begin{array}{l}\text { considering the irdemo graphic characteristics. } \\
\text { Discussion }- \text { Silence behaviors vary depending on the participation of employees in recreational } \\
\text { activities. In order to ensure that the employees are motivated, determined and open to innovation, } \\
\text { their motivation is increased through recreation activities and they are not allowed to show silence. } \\
\text { Low participation of employees in recreational activities causes employees to choose to remain silent } \\
\text { for various reasons. }\end{array}$
\end{tabular}

\section{GİRIŞ}

Küreselleşme ve teknolojik ilerlemelerin etkisi, insan yaşamındaki çalışma sürelerinin kısalması ve kişi başına düşen gelirin artması insanların ihtiyaçlarının farklılaşmasına yol açmıştır. Bu sayede insanlar boş zamanlarını değerlendirebilecekleri, çalışma hayatlarından kısa süreliğine de olsa uzaklaşıp bedensel ve zihinsel yorgunluklarını giderebilecekleri farklı yerleri ziyaret etme, eğlenme, dinlenme gibi ihtiyaçlara yönelmişlerdir (Ercan, 2014:1). İşte bu yöneliş Rekreasyon faaliyetlerini ortaya çıkarmıştır.

Rekreasyon, uygun faaliyet seçimi yapılması ve organize bir programa katılmak şartıyla iyi bir lider önderliğinde kişinin iş verimini artırmakta ya da başarısına olumlu katkı sağlamaktadır (Tezcan, 2007:1). Rekreasyon boş zamana yönelik bir olgu olarak görülse de çalışanların rekreasyon aktiviteleriyle iyi bir 
şekilde motive edilmesiyle onların yalnızca özel hayatının değil aynı zamanda iş hayatının ve performansının da doğrudan etkilendiği anlaşılmış ve böylece işyeri rekreasyonu ortaya çıkmıştır (Küçük, 2017:27).

İnsan yaşamının önemli bir kısmı iş yerinde geçmektedir. Bundan dolayı, işgörenin işinden aldığı haz ve hissettiği tatmin çok önemlidir. İşgörenin işinden aldığı haz ve tatmin aşamalı olarak, onun ruhsal ve bedensel sağllğı üzerine de yansımakta, aile yaşamındaki mutluluk ise örgütte verimliliği arttırmaktadır (Ceyhan ve Siliğ, 2005:44). Bu bağlamda işgörenler için düzenlenecek rekreasyon aktiviteleri işe bağlllı̆̆1 etkileyeceği gibi işgörenlerin motive olarak yaptığı işten tatmin olmasını sağlayacak ve böylece işgören performansı artacak ve örgütte verimlilik yükselecektir.

Örgütlerin başarısı işgörenlerin örgüte karşı olumlu geri dönüşler yapmasına, kazanmış oldukları bilgileri, tecrübelerini, ilgilerini ve kaygılarını ifade edebilecekleri bir çalışma ortamı sağlanmasına bağlıdır. Bu nedenle yöneticiler, işgörenlerin verimli ve etkili çalışmasını da sağlayabilecek yapıcı değişikliklere gitmek durumunda kalmaktadır (Arslan ve Yener, 2016:174).

Her örgütün, işgörenine, kendisine, topluma karşı çeşitli yükümlülükleri vardır. Ruhsal, toplumsal ve yasal sözleşmelere göre örgütlerin işgörenlerine karşı yerine getirmesi gereken birincil yükümlülügü işgörenlerinin ruhsal, toplumsal ve maddi gereksinimlerini karşılamaktır. Örgütler daha önceleri üstlerine düşen bu yükümlülükleri tam anlamıyla yerine getirmemekteydi. Neredeyse hızına yetişilmesi mümkün olmayan teknolojik gelişmelerin yaşandığı günümüzde ise çalışma yaşamında insan faktörü büyük önem kazanmıştır (Ceyhan ve Siliğ, 2005:44). Bu konudaki farkındalığın artması da örgütlerin işgörenlerine yönelmelerini zorunlu kılmıştır (Kök ve Özcan, 2012:114).

Örgütler, amaçlarına ulaşmak için işgörenlerine daha fazla önem vermeye onlara daha fazla yatırım yapmaya, nitelikli ve verimli işgücünün oluşturulması ve örgütsel verimliliğin arttırılması amacıyla insan faktörüne ve gelişimine daha çok önem vermeye başlamışlardır(Ceyhan ve Siliğ, 2005:44).

Günümüzde örgütler takım çalışması, kendi kendini yöneten gruplar, örgütsel demokrasinin tabana yayılması, güçlendirme gibi yöntem ve uygulamaları daha fazla önemsemektedir (Gürdoğan ve Atak, 2016:). İşgörenlerinin yaptıkları iş doğrultusunda daha fazla sorumluluk almasını, yaratıcı olmasını istemektedir. Örgütler kendi içlerinde özgüvenleri yüksek bireyler görmek istemektedir (Yanık, 2012:1). Bu çağdaş yönetim uygulamaları sonucunda işgörenler arasında daha fazla düzeyde bilgi paylaşımı ve uyumlu bir ortamın oluşması beklenirken, bazı nedenlerden dolayı işgörenlerin örgütlerine karşı duyarsız ve birçok konuda görüş bildirmeyip sessiz kaldıkları görülmektedir. İşgörenlerin görüşlerini kendine saklaması örgütte yeni fikirlerin, sinerjinin ve yaratıcılı̆̆ın ortaya çıkmasına engel olmakta, işletmenin amaçlarına ulaşmasını engellemektedir (Gürdoğan ve Atak, 2016).

Örgütsel sessizlik olarak ortaya çıkan bu durum işletmelerde aksaklıkların giderilmesine veyahut aksayan yönlerin iyileştirilmesine imkan vermemektedir (Ercan, 2014:2). Yine bu durum işgücü devrine, motivasyon düşüklüğüne ve örgütsel amaçlara ulaşma yönünde düşük çaba göstermeye neden olmaktadır. Örgütlerde, sorunların dile getirilmemesiyle işgörenin örgütsel bağlllğında azalma görülebilmekte ve bu da işgörenlerde performans düşüklüğüne neden olmaktadır (Çaloğlu, 2014:1). İşgören performansının düşmesine bağlı olarak da verimlilik düşmekte, işletme hedeflerinden uzaklaşmakta, rakiplerine karşı başarısız konuma düşmekte ve süreklilik arz edemez hale gelmektedir (Ercan, 2014:3).

Özellikle hiyerarşinin olduğu örgütlerde bu durum daha belirgin bir şekilde ortaya çıkmaktadır. İşgörenler örgütsel hiyerarşi içerisinde negatif bir tepki ya da bir tehditle karşılaşmamak için genellikle bilgilerini, önerilerini paylaşmakta isteksiz olmaktadırlar (Özgan ve Külekçi, 2012:33). Hiyerarşik yapılanmanın belirgin olduğu bankalarda da bu durumun ortaya çıkma olasılığı yüksek olabilir.

Türk alan yazını incelendiğinde işgören sesliliği yerine daha çok örgütsel sessizlik olgusunun çalışıldığı görülmektedir. Yapılan alan yazın taramasında işgören sesliliğine dair sadece bir tane kuramsal çalışmaya rastlanmıştır. Ayrıca Özdemir ve Sarıoğlu "örgütsel ses ve sessizlik" adıyla kendi geliştirdikleri bir ölçek ile bu konuya kısmi katkı sağlamışlardır. Bununla birlikte seslilik kavramı alan yazında "sessizlik" kavramı bağlamında incelendiğinden dolayı konuyla ilgili sessizlik üzerine daha çok çalışma olduğu görülmektedir (Arslan ve Yener 2016:174) 
İşgören sesliliği kavramı Türk alan yazınında hak ettiği yeri bulamamış olmakla birlikte diğer ülkelerde son birkaç yılda işgören sesliliğine dair yapılan araştırmaların sayıca artması, konunun halen ilgi çekiciliğini koruduğunun bir kanıtıdır. İşgören sesliliğinin farklı uygulamaları, farklı tanımlamalarını da beraberinde getirmiştir. İşgören sesliliği, işgörenlerin iş ile ilgili şikayetlerini yönetime bildirmesini ifade ederken aynı zamanda işgörenlerin karar alma sürecindeki rolü olarak da tanımlanabilir (Arslan ve Yener 2016:174).

Örgütsel sessizlik ile ilgili çalışmalar ülkemizde yeni başlamış olsa da gelişmiş ülkelerde bu konuyla ilgili çeşitli çalışmalar yapılmıştır. Örgütsel sessizliğin tarihi sürecini üç grupta inceleyebiliriz (Gülşen, 2015:23)

İlk olarak 1970 ve 1980 ortalarına kadar olan dönemde yapılmış olan çalışmalarda sosyal bilimciler konuşma ve sessizliğin farklı şekillerine değinmişlerdir. Özellikle 1970 yılında Hirschman"ın yaptığı çalışma bu dönemin en güzel örneğidir.

İkinci grup ise 1980"li yılların ortasından 2000"li yıllara kadar olan dönemi kapsamaktadır. Bu dönemde konuşma ve sessizlik sorun bildirme, ilkeli örgütsel muhalefet, konu benimsetme, şikayetçi olma gibi yeni araştırmalarla genişletilmiştir. Yine bu zaman diliminde örgütsel adaletle ilgili ilk incelemeler de işgörenlerin konuşması üzerine yoğunlaşmıştır. 1990"lı yılların sonunda ise çalışmalarda sağır kulak sendromu ve sosyal dışlama gibi konulara yoğunlaşılmıştır.

Son olarak 21. Yüzyıldaki çalışmalar ise üçüncü grubu kapsamaktadır. Bu dönemde konuşma ve sessizlik ile ilgili çalışmalarda artış olmuştur. Sessizlik konusu konuşmanın zıttı olarak görülmüştür. Örgütsel sessizlik konusu yönetimsel ve psikoloji ile ilgili çeşitli dergilerde yer almıştır. Özellikle Morrison ve Milliken tarafından 2000 ve $2003^{\circ}$ te Van Dyne tarafından $2003^{\circ}$ te örgütsel sessizlik ile ilgili yapılmış araştırmalar bunlara örnek verilebilir. Örgütte ki işgörenler bir örgütün başarısı için kritik öneme sahip olan değişimin, yaratıcılığın, öğrenmenin ve yeniliğin temel kaynağı olarak görülmektedir. Fakat pek çok çalışan çeşitli nedenlerden dolayı örgütlerinde ki sorunlarla ilgili konuşma konusunda isteksiz davranmaktadır (Gülşen, 2015:24).

Özel sektör ve kamusal alan olarak ayırmaksızın iş dünyasında rekabet üstünlüğü elde etmek, başarı sağlamak, kalite ve verimliliği arttırmak, müşteri memnuniyetini oluşturmak ve sadakatini sağlamak ancak insana verilen önemin büyüklüğüyle mümkündür. Çünkü hizmeti eş zamanlı üreten ve sunan insandır. Bu durumda, işgörenlerin işletme çıkarları doğrultusunda başarıya ulaşması ve bu başarıyı sürdürmesi çalışma koşullarının ve sağlanan imkanların beklentilere uygun olmasıyla mümkündür. İşgörenlerin örgüte yönelik fikirlerini ve düşüncelerini rahat bir şekilde ifade edebilmelerine fırsat tanımak, onlardan en üst düzeyde verimlilik sağlayarak örgütün hedeflerine daha hızlı ve daha kolay ulaşması bir basamak olmaktadır (Yavuz, 2016). Bu perspektif ile, işgörenlerin örgüte yönelik fikir ve düşüncelerini ifade etmeleri yerine sessizliği seçmeleri, örgütteki aksaklıkların ya da eksikliklerin giderilmesi karşısında duvar örerek işletmenin başarısızlığına zemin hazırlayabilmektedir.

\section{Yöntem}

Bu araştırmanın amacl; işgörenlere yönelik olarak düzenlenen rekreasyonel aktivitelerin örgütsel sessizliğe etkisinin belirlenmesidir. Bu araştırmada nicel araştırma yöntemi ve betimsel araştırma modeli kullanılmıştır. Betimsel araştırma modeli, bir konudaki herhangi bir durumu saptamayı amaçlar.

Betimsel araştırma modeli ile araştırmaya katılan çalışanların demografik özellikleri ile ilgili bilgiler verilerek katılımcıların genel bir profili belirlenmeye çalışılmıştır. Sonrasında ise çalışanların demografik özelliklerine ilişkin bulguları yorumlamak; rekreasyon aktivitelerine yönelik düşüncelerini belirlemek için frekans ve yüzde analizinden yararlanılmıştır. Örgütsel sessizlik ölçeğine ilişkin faktör analizi yapılmıştır. Faktör analizleri sonucunda, elde edilen boyutların güvenilirliğinin test edilmesinde güvenilirlik katsayıları (Cronbach's Alpha) hesaplanmıştır. Ayrıca, çalışanların sessizlik nedenlerinin demografik özelliklerine ve rekreasyon aktivitelerine ilişkin farklılık gösterip göstermediğini belirlemek için Mann-Whitney U Testi ile Kruskal-Wallis Testinden yararlanılmıştır.

Bu araştırmada evrene ilişkin ana kütleyi, Türkiye'de çalışan bireyler oluşturmaktadır. TÜiK 2018 Temmuz verilerine göre 29 milyon 265 bin kişi istihdam edilmektedir. Bu kapsamda çalışanların tümüne ulaşmak maddiyat ve zaman kısıtlılığından dolayı çok zordur. Dolayısıyla bu çalışmada Türkiye'nin yedi bölgesini temsil edecek şekilde tesadüfi olmayan "Kartopu" Örnekleme yöntemi kullanılmıştır. Kartopu örnekleme yönteminde, önce evrene dahil birisiyle temas kurulur, sonra onun tanıdıkları ve çevresindeki bireyler ile 
iletişime geçerek örneklem çoğaltılır (Nakip, 2003:183). Sessizlik ölçeği ve rekreasyonel ifadelere ilişkin anket hazırlanması sonrasında, örnek kütleye benzer nitelikteki 38 kişiye anket formları uygulanmıştır. Bu örneklem yönteminde, örnek sayısı ve örnek içinde yer alan elemanlar istatistiksel olarak tesadüfî olmayan yollarla belirlenmiştir (Özoğlu, 2010:76). Örneklem büyüklügünü etkileyen belirleyici faktörlerin (örnekleme hatası, güven düzeyi ve oranlar) dikkate alınmasıyla evreni temsil yeteneğine sahip örneklemden yola çıkarak, ilgili örneklem büyüklügünün hesaplamasında, 0,05 anlamlılık düzeyinde ve 0,05 örneklem hatasında belirtilen 100.000 'den büyük evren büyüklüklerinde 384 sayısı örneklem için yeterli bulunmaktadır (Öztürk ve Kenzhebayeva, 2013:38).

Örgütsel sessizlik soruları için 5'li likert tipi ölçek kullanılmıştır. Her bir soru için 1=kesinlikle katılmıyorum, 2=katılmıorum, 3=ne katılıyorum, ne katılmiyorum, 4=katılıyorum, 5=tamamen katıliyorum şeklinde derecelendirilmiştir.

\section{Bulgular}

\section{Çalışanların Demografik Özelliklerine İlişkin Bulgular}

Tablo 1'de çalışanların demografik ve mesleki özelliklerine göre dağılımları gösterilmiştir. Çalışanların demografik özelliklerine ilişkin bulguları; cinsiyet dağılımı, yaş grupları, eğitim durumu ve medeni durum oluşturmaktadır. Çalışanların mesleki özelliklerine ilişkin bulguları ise; kurumdaki çalışma süresi ve çalışanın geliri oluşturmaktadır.

Tablo 1.Çalışanların Demografik ve Mesleki Özelliklerine İlişkin Frekans ve Yüzde Değerleri

\begin{tabular}{lcclcc}
\hline Cinsiyet & $\mathbf{N}$ & $\mathbf{\%}$ & Medeni Durum & $\mathbf{N}$ & $\mathbf{\%}$ \\
\hline Kadın & 183 & 47,2 & Bekar & 212 & 54,6 \\
Erkek & 205 & 52,8 & Evli & 176 & 45,4 \\
Toplam & 388 & 100,0 & Toplam & 388 & 100,0 \\
\hline Yaş Grubu & $\mathbf{N}$ & $\mathbf{\%}$ & Çalışanın Geliri & $\mathbf{N}$ & $\mathbf{\%}$ \\
\hline $18-23$ yaş & 44 & 11,3 & $1000-2000$ TL & 71 & 18,3 \\
$24-29$ yaş & 141 & 36,3 & $2001-4000$ TL & 163 & 42,0 \\
$30-35$ yaş & 128 & 33,0 & $4001-6000$ TL & 131 & 33,8 \\
36 yaşveüzeri & 75 & 19,4 & 6000 veüzeri TL & 23 & 5,9 \\
Toplam & 388 & 100,0 & Toplam & 205 & 100,0 \\
\hline Eğitim Durumu & $\mathbf{n}$ & $\mathbf{\%}$ & Kurumda Çalışma Süresi & $\mathbf{N}$ & $\mathbf{\%}$ \\
\hline Ilköğretim & 4 & 1,0 & 1 yıldan az & 72 & 18,6 \\
Lise & 87 & 22,4 & $1-5$ yıl & 152 & 39,2 \\
Önlisans & 26 & 6,7 & $5-10$ yll & 118 & 30,4 \\
Lisans & 179 & 46,1 & $10-15$ yıl & 21 & 5,4 \\
Yüksek lisans & 57 & 14,7 & 15 yıl ve üzeri & 25 & 6,4 \\
Doktora & 35 & 9,0 & & 388 & 100,0 \\
Toplam & 388 & 100,0 & Toplam & & \\
\hline
\end{tabular}

Tablo 1'de, çalışanların demografik verilerine bakıldığında; cinsiyet dağılımına göre çalışanların $\% 47,2^{\prime}$ sini $(\mathrm{n}=183)$ kadınlar, \%52,8'ini (n=205) ise erkek çalışanların oluşturduğu görülmektedir. Yaş grubuna göre çalışanların \%11,3'ünü (n=44) 18-23 yaş arası bireyler, \%36,3'ünü (n=141) 24-29 yaş arası bireyler, \%33,0'ünü $(n=128)$ 30-35 yaş arası bireyler, \%19,4'ünü $(n=75)$ ise 36 yaş ve üzeri bireyler oluşturmaktadır. Eğitim durumuna göre çalışanların \% 1'i (n=13) ilköğretim, \%22,4'ü $(n=87)$ lise, \% 6,7'si (n=26) ön lisans, \% 46,1'i ( $\mathrm{n}=179)$ lisans, \% 14,7'si (n=57) yüksek lisans ve \%9,0'ı doktora mezunudur. Çalışanların kurumdaki çalışma süresine göre; 1 yıldan az çalışanlar \% 18,6 ( $\mathrm{n}=72)$, çalışanların \% 39,2'sini ( $\mathrm{n}=152)$ 1-5 yıl arası çalışan grup, \% 30,4'ünü (n=118) 5-10 yıl çalışan grup, \% 5,4'ünü (n=21) 10-15 yıl çalışan grup ve \%6,4'ünü (n=25) de 15 yıl 
ve üzeri çalışan grup oluşturmaktadır.

Tablo 1'de çalışanların demografik özelliklerine ilişkin değişkenlerin dağılımına bakıldığında; Kadın ve erkek bireylerin sayıları 2019 yılı TÜiK Türkiye nüfus ortalamasına yakın olarak neredeyse birbirine eşit görülmektedir. Araştırmaya katılan bireyler yaş olarak çoğunlukla 24-35 yaş aralığındadır. Medeni durum olarak evliler bekarlara oranla daha çok ve kurumda çalışma sürelerinin çoğunluğunu 1-10 yıl arasında olan bireyler oluşturmaktadır. Gelir durumları incelendiğinde araştırmaya katılan bireylerin \%75,8'inin 2000 ile 6000 TL arasında olarak 2019 net asgari ücret ve üzerinde gelir sağladıkları görülmektedir.

Tablo 2. Örneklem Grubunu Oluşturan Bireylerin İşYerinde Rekreatif Etkinliklere Yönelik İfadelerinin Yüzde Frekans Tabloları $(\mathrm{n}=388)$

\begin{tabular}{|c|c|c|c|}
\hline \multicolumn{4}{|l|}{ İFADELER } \\
\hline & & $\mathrm{n}$ & $\%$ \\
\hline \multirow[t]{2}{*}{ İşyerinizde çalışma saatleri dışında zorunlu spor etkinlik saatleri bulunuyor mu? } & Evet & 21 & 5,4 \\
\hline & Hayır & 367 & 94,6 \\
\hline \multirow{2}{*}{ Çalıştığınız işyerinde çalışanlara yönelik işyeri içi turnuvalar düzenleniyor mu? } & Evet & 129 & 33,2 \\
\hline & Hayır & 259 & 66,8 \\
\hline \multirow{2}{*}{$\begin{array}{l}\text { Rekreasyon (boşzamanlarıdeğerlendirme ) etkinliklerine katılmanızın, size rahatlatarak, } \\
\text { işveriminizi arttıracağını düşünür müsünüz? }\end{array}$} & Evet & 369 & 95,1 \\
\hline & Hayır & 19 & 4,9 \\
\hline \multirow{2}{*}{$\begin{array}{l}\text { Rekreasyon ( boşzamanlarıdeğerlendirme ) etkinliklerine katılmak sizce iş stresi ve } \\
\text { günlük stresler ile başa çıkabilmenize yardımcı olur mu? }\end{array}$} & Evet & 371 & 95,6 \\
\hline & $\overline{\text { Hayır }}$ & 17 & 4,4 \\
\hline \multirow[t]{2}{*}{ İşyerinizde spora teşvik edici çalışmalar yapılıyor mu? } & Evet & 90 & 23,2 \\
\hline & Hayır & 298 & 76,8 \\
\hline \multirow[t]{2}{*}{ Çalıştığınız işyerinde size ve ailenize yönelik sosyal aktiviteler düzenleniyor mu? } & Evet & 128 & 33,0 \\
\hline & Hayır & 260 & 67,0 \\
\hline \multirow{2}{*}{$\begin{array}{l}\text { İşyerinizde çalışanlara yönelik performans arttırma amaçlı etkinlikler düzenleniyor } \\
\text { mu? }\end{array}$} & Evet & 103 & 26,5 \\
\hline & Hayır & 285 & 73,5 \\
\hline
\end{tabular}

Tablo 2'deki iş yerinizde çalışma saatleri dışında zorunlu spor etkinlik saatleri bulunuyor mu ifadesinden elde edilen bulgulara göre, katılımcıların \% 5,4'ünün $(n=21)$ işyerlerinde çalışma saatleri dışında zorunlu spor etkinlik saatleri olduğu, \%94,6'sının ( $\mathrm{n}=367$ ) işyerlerinde çalışma saatleri dışında zorunlu spor etkinlik saatleri olmadığı belirlenmiştir. Tablo 2'dekibir diğer ifade olan çalıştığınız işyerinde çalışanlara yönelik işyeri içi turnuvalar düzenleniyor mu? sorusuna katılımcıların \% 33,2'sinin ( $\mathrm{n}=129)$ evet cevabını verirken, $\% 66,8$ 'inin ( $\mathrm{n}=259)$ hayır cevabını verdiği görülmektedir. Rekreasyon ( boş zamanları değerlendirme ) etkinliklerine katılmanızın, sizi rahatlatarak, iş veriminizi arttıracağını düşünür müsünüz ifadesine evet diyenler katılımcıların \% 95,1'ini(n=369), hayır diyenler katılımcıların \% 4,9'unu ( $\mathrm{n}=19)$ oluşturmaktadır. Tabloda yer alan bir diğer ifade olan 'Rekreasyon ( boş zamanları değerlendirme ) etkinliklerine katılmak sizce iş stresi ve günlük stresler ile başa çıkabilmenize yardımcı olur mu?' sorusuna evet yanıtını verenler katılımcıların \% 95,6'sını ( $\mathrm{n}=371)$, hayır yanıtını verenler ise katılımcıların \% 4,4'ünü $(\mathrm{n}=17)$ oluşturmaktadır. Tablo 2' deki iş yerinizde spora teşvik edici çalışmalar yapılıyor mu? İfadesinden elde edilen bulgulara göre, katılımcların \% 23,2'sinin ( $\mathrm{n}=90)$ işyerinde spora teşvik edici çalışmalar yapılırken, \%76,8'inin ( $\mathrm{n}=298)$ işyerinde spora teşvik edici çalışmalar yapılmadığı belirlenmiştir. Çalıştığınız iş yerinde size ve ailenize yönelik sosyal aktiviteler düzenleniyor mu? İfadesine evet yanıtını verenler katılımcıların \% 33,0'ını (n=128), hayır yanıtını verenler katılımcıların \% 67,0'ını (n=260) oluşturmaktadır. İş yerinizde çalışanlara yönelik performans arttırma amaçlı etkinlikler düzenleniyor mu? İfadesini evet olarak yanıtlayanlar katılımcıların \% 26,5'ini (n=103), hayır olarak yanıtlayanlar katılımcıların \% 73,5'ini ( $\mathrm{n}=285)$ oluşturmaktadır. 
P. Canbolat - E. Yavuz 11/2 (2019) 1262-1269

Tablo 3. Örneklem Grubunu Oluşturan Bireylerin Rekreasyon ve Sosyal Aktivitelere Katılımlarına Yönelik Yüzde ve Frekans Tabloları

\begin{tabular}{|c|c|c|c|}
\hline Ífadeler & Siklık & $\mathbf{n}$ & $\%$ \\
\hline \multirow[t]{6}{*}{$\begin{array}{l}\text { Ne sıklıkla spor aktivitelerine } \\
\text { zaman ayırıyorsunuz? }\end{array}$} & Her gün & 15 & 3,9 \\
\hline & İki Haftada Bir & 31 & 8,0 \\
\hline & Hiç Katılmıyorum & 58 & 14,9 \\
\hline & Haftada 2-3 Gün & 88 & 22,7 \\
\hline & Haftada 1 Gün & 93 & 24,0 \\
\hline & Yılda Birkaç Kez & 103 & 26,5 \\
\hline Toplam: & & 388 & $\% 100$ \\
\hline \multirow[t]{6}{*}{$\begin{array}{l}\text { Ne sıklıkla sosyal aktivitelere } \\
\text { zaman ayırıyorsunuz?. }\end{array}$} & Her gün & 5 & 1,3 \\
\hline & İki Haftada Bir & 86 & 22,2 \\
\hline & Hiç Katılmıyorum & 25 & 6,4 \\
\hline & Haftada 2-3 Gün & 83 & 21,4 \\
\hline & Haftada 1 Gün & 95 & 24,5 \\
\hline & Yilda Birkaç Kez & 94 & 24,2 \\
\hline Toplam: & & 388 & $\% 100$ \\
\hline
\end{tabular}

Tablo 3'de bulunan ne siklıkta spor aktivitelerine zaman ayıriyorsunuz ifadesinden elde edilen bulgulara göre, katılımcıların \% 26,5'inin ( $\mathrm{n}=103)$, spor aktivitelerine yılda birkaç kez zaman ayırdığı belirlenmiştir. Spor aktivitelerine haftada 1 gün zaman ayırdığını belirtenler katılımcıların \% 24,0'ını (n=93), haftada 2-3 gün zaman ayırdığını belirtenler katılımcıların \% 22,7'sini ( $n=88)$, hiç zaman ayırmadığını belirtenler katılımcıların \% 14,9'unu ( $n=58)$, iki haftada bir zaman ayırdığını belirtenler katılımcıların \% 8,0'ını (n=31), her gün zaman ayırdığını belirtenler ise katılımcıların \% 3,9'unu (n=15) oluşturmaktadır.

Tablo 3'de yer alan ne sıklıkla sosyal aktivitelere zaman ayırıyorsunuz ifadesinden elde edilen

bulgulara göre, katılımcıların \% 24,2'sinin ( $=94)$, sosyal aktivitelere yılda birkaç kez zaman ayırdı̆̆ belirlenmiştir. Sosyal aktivitelere haftada 1 gün zaman ayırdı̆̆ını belirtenler katılımcıların \% 24,5'ini (n=95), haftada 2-3 gün zaman ayırdığını belirtenler katılımcıların \% 21,4'ünü (n=83), hiç zaman ayırmadığını belirtenler katılımcıların \% 6,4'ünü (n=25), iki haftada bir zaman ayırdığını belirtenler katılımcıların \% 22,2'ini (n=86), hergün zaman ayırdığını belirtenler ise katılımcıların \% 1,3'ünü (n=5) oluşturmaktadır.

Tablo 4. Sessizlik Faktörleri ile Cinsiyet Arasındaki Mann-Whitney U Testi Analizi (n=388)

\begin{tabular}{|c|c|c|c|c|c|c|c|}
\hline Sessizlik Faktörleri & $\mathbf{N}$ & Medyan & $\begin{array}{c}\text { Sira } \\
\text { Ortalaması }\end{array}$ & $\begin{array}{c}\text { Sira } \\
\text { Toplamı }\end{array}$ & S.hata & $\mathbf{U}$ & $\mathbf{P}$ \\
\hline \multirow[t]{2}{*}{ 1.Faktör: Sosyal ilişkilerin Bozulması Faktörü } & Kadın 183 & 3,125 & 237,91 & 43538,00 & \multirow{2}{*}{1,100} & \multirow{2}{*}{\multicolumn{2}{|c|}{$10.813,000$}} \\
\hline & Erkek 205 & 2,000 & 155,75 & 31928,00 & & & \\
\hline \multirow{2}{*}{$\begin{array}{l}\text { 2.Faktör: Güven Sorunu ile işi Kaybetme } \\
\text { Korkusu }\end{array}$} & Kadın 183 & 3,000 & 229,27 & 41955,50 & \multirow{2}{*}{1,099} & \multirow{2}{*}{\multicolumn{2}{|c|}{$12.395,000$}} \\
\hline & Erkek 205 & 2,000 & 163,47 & 33510,50 & & & \\
\hline \multirow{2}{*}{$\begin{array}{l}\text { 3.Faktör: Yönetim Politikalarının Sessizleştirmesi } \\
\text { Faktörü }\end{array}$} & Kadın 183 & 2,600 & 191,85 & 35108,00 & \multirow[b]{2}{*}{1,098} & \multirow{2}{*}{\multicolumn{2}{|c|}{$18.272,659$}} \\
\hline & Erkek 205 & 3,000 & 196,87 & 40358,00 & & & \\
\hline \multirow{2}{*}{$\begin{array}{l}\text { 4.Faktör: İş ile ilgili Mevcut Durumu Koruma } \\
\text { Faktörü }\end{array}$} & Kadın 183 & 3,600 & 223,19 & 42674,00 & \multirow[b]{2}{*}{1,098} & \multirow[b]{2}{*}{11.677} & \\
\hline & Erkek 205 & 2,000 & 159,96 & 32792,00 & & &, 000 \\
\hline \multirow[t]{2}{*}{ 5.Faktör: Deneyim ve Bilgi Yetersizliği Faktörü } & Kadın 183 & 2,400 & 201,08 & 36798,00 & \multirow{2}{*}{1,098} & \multirow{2}{*}{17.553} & 272 \\
\hline & Erkek 205 & 2,000 & 188,62 & 38668,00 & & &, $2 / 3$ \\
\hline
\end{tabular}


Tablo 4'te gösterilen sessizlik faktörleri ile cinsiyet değişkeni üzerinde yapılan Mann-whitney u testine göre cinsiyet ile 3. faktör (yönetim politikalarının sessizleştirilmesi faktör), ile 5. faktör (deneyim ve bilgi yetersizliği faktörü) arasında anlamlı bir dağılım bulunmamaktadır. Cinsiyet ile 1 faktör (sosyal ilişkilerin bozulması faktörü), 2. faktör (güven sorunu ile işi kaybetme korkusu faktörü) ve 4. faktör olan(iş ile ilgili mevcut durumu koruma faktörü) arasında istatistiksel olarak anlamlı bir fark bulunmaktadır.

Tablo 5. İşörenlerin Sessizlik Algıları ve Rekreasyon Aktivitelerine Katılım Durumlarının Korelasyon Analizi Sonuçları

\begin{tabular}{llll}
\hline & \multicolumn{4}{c}{ İşgörenlerin Rekreasyon aktivitelerine katılım durumu } \\
\cline { 2 - 4 } & $\mathrm{r}$ & $\mathrm{P}$ & $\mathrm{n}$ \\
\hline Sessizlik Ölçeği Yanıtlarının Ortalaması &,- 003 &, 958 & 388 \\
\cline { 2 - 4 }
\end{tabular}

$\mathrm{r}$ : correlation coefficent $\quad$ p: sig. (2-tailed)

İşgörenler için yapılan rekreasyon aktiviteleri ile örgütsel sessizlik arasında bir ilişki olup olmadığını belirlemek için yapılan ve Tablo 5'de sunulan korelasyon analizi sonuçlarına göre tezin ana hipotezini oluşturan rekreasyon aktiviteleri ile örgütsel sessizlik arasında ilişki bulunmamaktadır.

\section{SONUÇ ve TARTIŞMA}

Örgütsel sessizlik yaşayan işgörenler örgüt için verimli olmamakla beraber zamanla tehdit oluşturabilirler. Özellikle hizmet sektöründe hizmet kalitesi büyük önem arz etmektedir. Bir hizmet özelliği olarak hizmetin eşzamanlı bir şekilde üretilip tüketiliyor olması örgütlerde insanı en önemli kaynak haline getirmektedir. Bu sebeple örgütler işgörenlerinin eğitimini, kalitesini, bilgi ve becerisini çok önemsemektedir. Hizmeti üreten işgörenlerin örgüte karşı yapacakları geri beslemeler sayesinde örgüt rekabet üstünlüğü, müşteri memnuniyeti gibi birçok olumlu avantaj elde edebilir. Ancak işgören örgütsel sessizlik yaşıyor ise örgüte herhangi bir geri besleme yapamayacağından örgütün gelişimine yönelik herhangi bir fayda da sağlayamayacaktır.

Çalışanlar için düzenlenen rekreasyon aktivitelerinin önemini vurgulamak ve rekreasyon aktiviteleri ile çalışanların sessizlik durumuna ait ilişkiyi ortaya koymayı amaçlayan bu çalışmadan elde edilen verilerden yola çıkılarak iş görenlerin örgüt içerisinde düzenlenen rekreasyon aktivitelerine katılım durumları ile örgütsel sessizlik arasında yapılan korelasyonel analize göre iki kavram arasında herhangi bir ilişki bulunamamıştır. Bunun sebebinin ise örgüt içerisinde düzenlenen rekreasyon aktivitelerinin düzensiz veya tatmin edici olmadığından kaynaklandığı düşünülebilir. Bununla birlikte araştırmaya dahil olan katılımcıların genel anlamda rekreasyon aktivitelerine katılım oranlarının düşük olması bu duruma etkide bulunmuş olabilir. Ayrıca bu çalışma kapsamı rekreasyon faaliyetlerinin spor ve sosyal aktivite boyutlarını ele aldığından dolayı örgütsel sessizlik durumunda olan bireylerin örgütten daha farklı veya daha spesifik beklentilerinin olduğunu düşündürmektedir. Buna istinaden ise örgütlerin işgörenlerinin beklentilerini iyi bir şekilde saptayıp buna göre hareket etmesi örgütler açısından olumlu sonuçlar doğuracaktır.Örgütsel sessizliğin örgütlere yönelik sonuçları olumsuz olduğundan verimliliği de düşüreceği öngörülebilir. Bunun önlenebilmesi için ise işgörenlerin beklentilerine yönelik tatmin düzeylerini yükseltecek faaliyet veya aktivitelerin belirlenip sunulması bu sonucu etkileyebilir. Aynı zamanda evren sayısının çok büyük olmasının da sonucu etkilediği düşünülmektedir. Daha büyük bir örneklem sayısına ulaşmak daha farklı sonuçlar verebilir. Buda konu hakkında çalışma yapmak isteyen araştırmacılara yol gösterebilir. 


\section{KAYNAKÇA}

Arslan, A. \& Yener, S. (2016). İşgören Sesliliği Ölçeğinin Türkçe’ye Uyarlanması Çalışması. Yönetim ve Ekonomi Araştırmaları Dergisi, 14(1), 173-191.

Ceyhan, A. A.,\&Siliğ, A. (2005). Banka çalışanlarının tükenmişlik düzeyleri ile uyum düzeyleri arasındaki ilişkiler.

Çaloğlu, D. Ö. (2014). Örgütsel sessizlik ve kültürel değişsenler üzerine ampirik bir araştırma. Yayınlanmamış Yüksek Lisans Tezi. Ufuk Üniversitesi, Sosyal Bilimler Enstitüsü, Ankara.

Ercan, A., (2014). "Sessizleşen Örgütlerde Öz Yeterlilik Algısının Rolü: Alanya'daki Konaklama İşletmeleri Üzerine Bir Araştırma", Yüksek Lisans Tezi, Akdeniz Üniversitesi Sosyal Bilimler Enstitüsü, Antalya.

Gürdoğan, A. \& Atak, O. (2016). Çalışanların Demografik Özellikleri İle Örgütsel Sessizlikleri Arasındaki İlişki: Beş Yıldızlı Otel Örneği. Journal of International SocialResearch, 9(44).

Gülşen, P. (2015). İşletmelerde Psikolojik Şiddet ve Örgütsel Sessizlik Arasındaki İlişki Üzerine Bir Araştırma. Yüksek Lisans Tezi, İstanbul Kültür Üniversitesi, Sosyal Bilimler Enstitüsü,İstanbul.

Hirschman, A. O. (1970). Exit, voiceandloyalty: Responsestodecline in firms, Organizations, andStates. Cambridge, London: Harvard UniversityPress

Kök, S. B. \& Özcan, B. (2012). Örgüt kültürünün oluşumunda etkili olan faktörler ve örgütsel bağllllk ilişkisi: bankacılık sektöründe bir araştırma. Girişimcilik ve Kalkınma Dergisi, 7(2).

Küçük, K. (2017). Örgütlerde düzenlenen rekreasyon etkinliklerinin çallşanların yabancılaşma düzeyleri ile ilişkisi. Yüksek lisans Tezi, Gazi Üniversitesi Sosyal Bilimler Enstitüsü, Ankara.

Milliken, F. J.,Morrison E. W., \&Hewlin, P. F. (2003). An exploratory study of employee silence: issues that employees don't communicateup wardand why. Journal of Management Studies, 40(6), 1453-1476. https://doi.org/10.1111/1467-6486.00387

Morrison, E. W.,\&Milliken, F. J. (2000). Organizational silence: a barrier to change and development in a pluralistic. The Academy Of Management Review, 25, 706-725.

Nakip, M. (2003). Pazarlama Araştırmaları Teknikler ve SPSS Destekli Uygulamalar. Ankara: Seçkin Kitabevi.

Özgan, H. \& Külekçi, A. G. E. (2012). Öğretim Elemanlarının Sessizlik Nedenleri ve Üniversitelerine Etkileri/The Reasons of Academic Staff Silence and Its Effect on Their University. e-International Journal of Educational Research, 3(4).

Özoğlu, Buket. (2010). Tüketici Odaklı Yaklaşım İle İnternet Bankacılığı FaaliyetleriniDeğerlendirmeye Yönelik Bir Uygulama. Erciyes Üniversitesi Sosyal

Öztürk, Y. Ve Kenzhebayeva, A. (2013). Turizm Sektöründe Hizmet Kalitesi: Türkiye ve Kazakistan'daki Termal Otel İşletmelerinde Karşılaştırmalı Bir Araştırma. Journal of Tourism and Gastronomy Studies, 1(4).

Tezcan, N. (2007). Rekreasyon etkinliklerinin çalışanların performansları üzerine etkilerinin incelenmesi: (kocaeli trakya birlik), Yayınlanmamış Yüksek Lisans Tezi, Sakarya Üniversitesi Sosyal Bilimler Enstitüsü, Sakarya.

Van Dyne, L.,Soon, A., \&Botero, I. C. (2003). Conceptualizing employee silence and employee voice as multidimensional constructs. Journal of Management Studies, 40(6), 1359-1392. https://doi.org/10.1111/14676486.00384

Yanık, C.(2012). Örgütsel sessizlik ve güven arasındaki ilişki ve eğitim örgütlerinde bir araştırma. Yeditepe Üniversitesi, Sosyal Bilimler Enstitüsü, Eğitim yönetimi ve Denetimi Anabilim dalı, yüksek lisans tezi, İstanbul. 